\title{
Application of Execution of Forced Money (Dwangsom) on Country Business Justice
}

\author{
Dezonda. R. Pattipaw*, Faisal Santiago* \\ Lecturelty Faculty of Law of Borobudur University
}

\begin{abstract}
Dwangsom is a sum of money stipulated by a judge in a verdict charged to the defendant and enforced if the defendant does not carry out the sentence specified. Dwangsom's obligation must be fulfilled or paid when the losing party does not comply with the contents of the decision (which is condemnatory). Execution can be interpreted as an action in the case of a court decision that has permanent legal force (inkracht). Execution of court decisions is the implementation of court decisions by or with the assistance of outside parties from the parties. Matters relating to the execution are the cancellation of the Decree followed by rehabilitation, administrative sanctions and execution of decisions to pay a sum of money (dwangsom). Article 116 paragraph (4) of the Administrative Court Law states that "In the event that the defendant is unwilling to implement a court ruling that has obtained permanent legal force, the official concerned is subjected to forced efforts in the form of payment of forced money and or administrative sanctions". The purpose of these provisions is "officials who do not carry out court decisions that have legal force are still subject to forced money", forced money is intended to be in the form of payment of a sum of money stipulated by the judge because his position was included in the verdict when he granted the plaintiff's claim. Forced money (dwangsom) is imposed by the judge with the intention that the decision in the subject matter is carried out by the defendant (the losing party). Dwangsom can only be applied to orders to carry out certain actions carried out by certain people and cannot be replaced / represented by others. The application of dwangsom cannot be applied to all PTUN decisions. The application of dwangsom can only be imposed on punishable PTUN decisions (condemnator decisions).
\end{abstract}

Keywords: Implementation of execution, forced money (dwangsom), PTUN

DOI: $10.7176 / \mathrm{JLPG} / 88-25$

Publication date: August $31^{\text {st }} 2019$

\section{A. Introduction}

The existence of a legal state clearly stated in the constitution, one of the elements of the rule of law is the functioning of a judicial institution that is independent and impartial judiciary, the judiciary is a place to seek truth and justice if there is a dispute or violation of law, both in framework for settlement of criminal, civil and administrative matters. The 1945 Constitution of the Republic of Indonesia, Article 24 concerning judicial power. ${ }^{1}$ Indonesia as a democratic country must empower its people, respect the rights of its people, and strive to to realize civil society. One of the important elements of the realization of popular sovereignty and civil society is the existence of a strong Administrative Court and a sense of justice for its people. Seeing this reality, it is clear that the existence of an executorial institution in the State Administrative Court and its legal basis is an urgent need.

State Administrative Decision is a written stipulation issued by a State Administration Agency or Act which contains State Administrative law actions based on applicable laws and regulations, which are concrete, individual, and final, which creates legal consequences for a person or legal entity civil. Therefore, a person or civil legal entity (community) who feels aggrieved due to the actions of the State Administration Agency or the issuing or not issuing a State Administrative Decree, makes the State Administrative Court a means to supervise the legal actions of the Tata Agency or Officer State Enterprises in the form of testing of State Administrative Decisions through lawsuits submitted to the State Administrative Court in order to seek justice and legal certainty due to the actions of the State Administration Agency.

Article 97 paragraph (9) of Law Number 5 of 1986 concerning State Administrative Courts (hereinafter brief in the Administrative Court Law) there are two types of obligations that must be carried out by the Defendant in a State Administrative Court decision as follows:

1. The obligation to revoke the relevant State Administrative Decision (which is sued). In this case, the provisions of Article 116 paragraph (2) of the Administrative Court Law apply, stating that in the case of four months after a Court decision that has obtained permanent legal force as referred to in paragraph (1) the Defendant does not fulfill his obligations as referred to in Article 97 paragraph (9) letter a of the PTUN Law, the disputed State Administrative Decision has no legal force. The consequence of this

\footnotetext{
${ }^{1}$ Indonesia, the 1945 Constitution of the Republic of Indonesia, Article 24 concerning judicial power paragraph (1) mentions "Judicial power power is an independent power to conduct justice to enforce law and justice and paragraph (2) states" Judicial power is exercised by a Court Agung and the judicial bodies that are under him in the general justice environment, the religious court environment, the military justice environment, the state administrative court environment, and by a Constitutional Court ".
} 
provision on the disputed decision that has been decided upon is that there is no need for any other action or effort from the court. ${ }^{1}$

2. The obligation to revoke the State Administrative Decree and issue a new State Administrative Decree or the obligation to issue a State Administrative Decision in the case of a claim based on Article (3) of the Administrative Court Law. In this case, the provisions of Article 116 paragraph (3) of the Administrative Court Law state that in the event that the defendant is determined to carry out its obligations as referred to in Article 97 paragraph (9) letters b and c of the Administrative Court Law, and after three months it turns out that the plaintiff submit an application to the Chair of the Court as referred to in paragraph (1) of Article 116 of the PTUN Law so that the Court orders the defendant to carry out the court ruling. If the defendant is not willing to implement a court ruling that has permanent legal force under the PTUN Law, the mechanism carried out by the Chief of Court proposes that matter to the superior agency according to the level of position. This is based on the principle because of the state administrative dispute (state administration), after the court ruled, if the arrogant official did not want to carry out the obligations imposed on him the matter was returned to the state administration, namely through the implementation of the government (bestuuer dwang). In terms of state administration or the administration of government, coercion (dwang) which is more effective is coercion that comes from the superior of an official. So, lawmakers prefer government coercion (bestuur dwang) so that State Administration Officers comply with court decisions.

The bestuur dwang mechanism provided is "the top agency of the official sued within two months after receiving notification from the Chairperson of the State Administrative Court must have ordered officials who do not carry out court decisions that have permanent legal force to implement the court ruling. If the superior of an official who does not carry out a court ruling that has permanent legal force does not heed the notification of the court, the Chairperson of the Court submits the matter to the President as the highest government authority to order the official to implement the court ruling. Based on the provision that the President's order to comply with court decisions to officials who do not carry out court decisions that have permanent legal force on court decisions is the highest form of bestuur dwang. ${ }^{2}$ Because the bestuur dwang mechanism is less effective, in the end the provisions of Article 116 of the Administrative Court Law which are favorable to the non-compliance of officials to court decisions are amended and the sanctions are confirmed as stipulated in Article 116 paragraph (4) of the Administrative Court Law. Article 116 paragraph (4) which states that "In the event that the defendant is not willing to implement a court ruling that has obtained permanent legal force, the official concerned is subject to forced efforts in the form of payment of a number of forced money and / or administrative sanctions". The purpose of these provisions is "officials who do not carry out court decisions that have legal force are still subject to forced money", forced money is intended to be in the form of payment of a sum of money stipulated by the judge because his position was included in the verdict when he granted the plaintiff's claim. Forced money (dwangsom) is imposed by the judge with the intention that the decision in the subject matter is carried out by the defendant (the losing party).

Forced money (dwangsom) is an attempt to make the defendant willing to carry out the contents of the decision, because the decision is not usually carried out without assistance from other parties. The provisions for the execution of the PTUN ruling which has permanent legal force seem to have been very promising to be able to provide legal certainty for justice seekers. But in practice the application of Article 116, especially paragraph (4) and paragraph (6) by PTUN is still very far from expectations. ${ }^{3}$ The implementation rules do not yet exist today in the form of Government Regulations or lower laws and regulations, even though paragraph (7) Article 116 of this Law has mandated that "Provisions concerning the amount of forced money, types of administrative sanctions, and procedures for implementation forced payment and / or administrative sanctions regulated by legislation ". 4

The decision of the State Administrative Court if it has permanent legal force, the State Administration Agency or Administration must carry out the obligations as stipulated in the Decision. The existence of the new State Administrative Court will be authoritative and meaningful for justice seekers, if the decisions can be carried out by the relevant State Administrative Apparatus in accordance with the contents of the Court's

\footnotetext{
${ }^{1}$ R. Wiryono, 2007, Hukum Acara Peradilan Tata Usaha Negara, Jakarta, Sinar Grafika, p. 202

${ }^{2}$ Indonesia, Law of the Republic of Indonesia Number 51 of 2009 concerning the Second Amendment to Law Number 5 of 1986 concerning State Administrative Courts, Article 116 paragraph (6) which states that "besides being announced in the local print media as referred to in paragraph (5), the Chair of the Court must submit this matter to the President as the highest authority to order the official to implement the court's decision, and to the people's representative institution to carry out oversight functions. The President as the highest leader of the government is obliged to provide guidance to government officials who do not carry out government functions properly. The delivery to the people's representative institutions is due to the function of the council to exercise control over the executive. Thus the institution of people's representation is also obliged to know the compliance of the agencies supervised by court decisions

${ }^{3}$ Titik Triwulan T, 2011, Hukum Tata Usaha Negara Dan Hukum Acara Peradilan Tata Usaha Negara Indonesia, Jakarta, Kencana Prenada Media Grup, p. 312.

${ }^{4}$ Paulus Effendi Lotulung, 2013, Hukum Tata Usaha Negara dan Kekuasaan, Jakarta, Salemba Humanika, p. 7.
} 
Decision. The most basic problem of the existence of the State Administrative Court lies in obeying or not adhering to the obligations stated in the Court Decision by the State Administration Agency. Sometimes the obligations contained in the Decision that must be carried out by the State Administration Agency (Defendant) are not carried out. Whereas the State Administration Agency should have the awareness to carry out the Decision, as stipulated in the provisions of Article 116 paragraph (3) of Law Number 5 Year 1986 as last amended by Law Number 51 of 2009 which states that: "In if the Defendant is determined to carry out the obligations referred to in Article 97 paragraph (9) letters b and c, and then after 90 (ninety) working days it turns out that the obligation is not implemented, the Plaintiff submits an application to the Chairperson of the Court as referred to in paragraph (1), so that the Court orders the defendant to carry out the Court Decision. A decision that instructs the Defendant (Agency or Administrative Officer) to carry out the obligations ordered in the Decision is therefore an obligation that must be carried out by the Defendant. ${ }^{1}$ The consequence for the State Administration Agency or Administration that does not carry out a Decision that has obtained permanent legal force then the State Administration Agency or Agency is subject to payment of a sum of forced money.

\section{B. Ormulation Of The Problem}

1. Why has the implementation of forced money (dwangsom) not been implemented in the State Administrative Court

2. How is the executorial power of decisions in the application of forced money (dwangsom) in the State Administrative Court

3. Can Daearh Autonomy hamper the decision of the State Administrative Court that has permanent legal force

\section{Research Methods}

Approach to the problem used in this paper is to use a normative juridical approach, namely library legal research and because this research is done by having library material. In this study, the type of research that is descriptive-analytical using the reason that the results obtained from the literature study are then analyzed and discussed using a systematic flow of discussion. Thus the results of the analysis and discussion are then described to facilitate the withdrawal of several conclusions and submission of suggestions

\section{Results And Discussion}

\section{Application of Forced Money Execution}

The lawmaker provides an alternative to the body authorized to conduct bestuurs to impose forced money in the interest as a substitute for bestuursdwang, the money will be lost for each time a violation is repeated or for each day (after the set time) continues. Forced money is mainly intended for situations where bestuursdwang is practically difficult to implement or will apply as a sanction that is too heavy. In the future, the law in all respects will link this alternative effort to the authority of bestuursdwang.

Factors causing non-compliance with the decisions of judges in the State Administrative Court in the form of forced money include: ${ }^{2}$

a. Weak / inadequate decisions of the Court of Justice itself.

Quality Judges' decisions, which are well formulated, right and fair, are demands. A quality Judge's decision will create authority which in turn will affect the implementation of the decision. There are still a lot of decisions made by the District Court Judges (including the Determination of Delays) taken without sufficient consideration, or with the consideration of being wrong, or even forced because of certain factors. There are important factors for creating a qualified judge's decision, namely Moral integrity (istiqomah) Knowledge and Understanding of Material Law and Formiil's Law. Based on good morality and equipped with sufficient material and formal legal knowledge, it is hoped that a quality decision can truly be realized. Upgrading, training and other scientific meetings among judges must be further improved and more focused towards the creation of quality judges' products.

b. The level of legal awareness of the Agency or TUN Officials and the existence of the interests of the TUN Agency / Officials towards the disputed TUN decision products. The existence of the personal interests / officials of the existence of the TUN decision issued and the weak level of legal awareness of the TUN Agency or Officials is very influential on whether or not the decisions of the TUN Judge Judge are obeyed, because normatively the execution of the Court Judges' decision relies more on the willingness of the Officials to carry it out ( floating execution).

c. Absence of forced institutions in the Peratun statutory regulations governing execution. The low quality of Judges' Decisions and the existence of official personal interests and the weak level of legal

\footnotetext{
${ }^{1}$ Marbun S. F, 2003, Peradilan Hukum Administrasi dan Upaya Administrasi di Indonesia, Jogjakarta, UII-Press, p. 259.

${ }^{2}$ Martiman Prodjohamidjojo, 2002, Hukum Acara Pengadilan Tata Usaha Negara, Jakarta, Ghalia Indonesia, p.. 165.
} 
awareness of the TUN Agency / Official coupled with the regulation of the execution of the Decree in the Laws and Regulations regulated by floating norms make the Decision of the Court no more teeth. The lack of strictness of the regulation resulted in the TUN Agency looking at the product of the judge named the verdict. Because after all there are no sanctions if the decision of the Peratun Judge is not obeyed. In theory, the law is not only regulating, so it is also sanctified and the sanctions are forced. Similarly, the judiciary, as a law enforcement agency, must absolutely be equipped with an instrument of forced / forced institutions. The three Courts that have existed before in Indonesia have indeed been completed by the forced institutions.

Compensation and dwangsom although both involve paying a sum of money, but are two different things. Compensation in the Law Number 5 of 1986 concerning State Administrative Courts is regulated in Article 53 paragraph (1) and Article 97 paragraph (10). Meanwhile forced money (dwangsom) is not regulated in the law. Compensation is a type of basic punishment charged to parties proven to have committed legal acts (onrechmatige) or broken promises (defaults). If the payment has been decided in the judge's decision, the amount must be met by the convicted person.

Dwangsom is a sum of money stipulated by a judge in a verdict charged to the defendant and enforced if the defendant does not carry out the sentence specified. Dwangsom is not a basic law, because even if a number of forced money has been determined in a verdict, the loser does not need to pay it or be burdened with the payment of the money if it has consciously or willingly obeyed the contents of the verdict. Dwangsom's obligation must be fulfilled or paid when the losing party does not comply with the contents of the decision (which is condemnatory). This is the main difference between compensation and dwangsom. Dwangsom is an asset, meaning additional punishment as a guardian and can be a coercive force so that a judge's decision is obeyed or implemented. Forced money is an indirect means of execution. Only decisions that contain punishments or the obligation to take certain actions to the losing party (condemnatory verdict), which can be imposed or applied by dwangsom. Decisions that are declatoir (which is explaining) and constitutief (decisions that are negating or giving rise to new legal conditions, can not be subject to or applied to dwangsom. ${ }^{1}$

Dwangsom was only implemented if a convicted official committed a certain action based on a judge's decision, he did not obey it. Dwangsom is applied (forced) to officials if it is against the judge's decision. When a judge issues a verdict, in essence it is acting as a pseudo legislator (pseudo-legislative body), therefore the judge's product (judges) is a legal product that is equal to legislation. Therefore, when the TUN Official does not comply with the judge's decision, the non-compliance is categorized as a violation of law or legislation. Offenses committed by officials are violations or faute personelle, so that the consequences of responsibility must also be personal (personal liability) ${ }^{2}$ from the person in office and not the institution or state. Which is in line with the "error" theory developed from the Conseil d'Etat Jurisprudence, which basically distinguishes between "official mistakes" (faute personnelle). Therefore, it is appropriate if an official does not obey or execute the decision of the court judge, then the imposition of forced money (dwangsom / astreinte) must be charged or paid for from the personal money of the person in office or at that time. It is unfair if the personal violations of the law consequently (in the form of dwangsom payments) are borne by the State. This is certainly very different when as an official in carrying out a task that even though it is in accordance with the laws and regulations, it can cause harm to the community. In this situation, the losses suffered by the community must be the responsibility of the state to compensate for the loss. ${ }^{3}$

The existence of a new State Administrative Court will be authoritative and meaningful for justice seekers, if the decisions can be carried out by the relevant State Administrative Apparatus in accordance with the contents of the dictum of the Court Decision. In other words the most basic problem of the existence of the State Administrative Court is precisely whether it is obeyed or not the obligations included in the Court's decision by the State Administration Agency. ${ }^{4}$ The implementation of the Decision of the State Administrative Court which is based on the awareness of the Agency / Officials of the State Business with tiered hierarchy (floating form) as stipulated in Article 116 of Act Number 5 of 1986, is apparently not effective enough to force the State Administration Official State Administrative Court. Therefore the enforcement of forced institutions in the form of payment of forced money (dwangsom / astreinte) as stated in Article 116 of Act Number 9 of 2004 states that "in the event that the Defendant is not willing to implement a Court Decision which has permanent legal force Forced efforts in the form of payment of forced money "Changes to the awareness of the State Administration Agency to carry out the contents of the State Administrative Court Decision can at least have a psychological impact to force the relevant officials to have a psychological impact to force the Official concerned to respect the

\footnotetext{
Soemaryo, 1999, Tuntunan Praktek Beracara Di Peradilan Tata Usaha Negara, Jakarta, Primamedia Pustaka, p. 89.

${ }^{2}$ Paulus Effendie Lotulung, 2000, Beberapa System Tentang Control Segi Hukum Terhadap Pemerintahan, Jakarta, Bhuana Ilmu Populer, p. 5.

${ }^{3}$ C.S.T. Kansil, 1996, Hukum Acara Peradilan Tata Usaha Negara, Jakarta, Pradnya Paramita, p. 78

${ }^{4}$ Supandi, 2002, Ganti Rugi Akibat Tindakan Pejabat Pemerintah Dalam RUU Administrasi Pemerintahan Dan Prospek Peradilan Tata

Usaha Negara, Medan, PT. Sofemdia, hlm. 12
} 
Court Decision besides It is also expected to increase public trust in the existence of the State Administrative Court. ${ }^{1}$

Its application in the State Administrative Court, in practice there are several legal issues that need attention, including: ${ }^{2}$

1. What types of decisions are subject to Forced Efforts

The decision of the State Administrative Court can be in the form of a declaratory verdict, which is only explaining. Constitutive decisions are those that negate or give rise to new legal conditions and condemnatory decisions which are punitive or contain the obligation to take certain actions against the losers, while according to the contents of the decision based on the provisions of Article 97 paragraph (7) Law Number 5 of 1986 concerning Judiciary State Administration can be in the form of a lawsuit rejected, a claim is granted, the claim is not accepted and the claim is dropped. The kinds of contents and the nature of the decisions of the State Administrative Court are not all decisions can be subjected to forced efforts, but only the verdicts that meet the requirements are: ${ }^{3}$

a. The verdict which states the claim is granted, that is, if the results of the examination at the trial prove that the arguments of the plaintiff's claim have been formally and materially proven and have been able to support the petition filed by the Plaintiff;

b. Decisions are condemnatory, namely decisions that are of a nature that give a burden or obligation to take certain actions to the State Administration Agency such as:

1. The obligation to revoke State Administrative Decrees that are declared null / invalid.

2. The obligation to issue a state / substitute State Administrative Decree.

3. The obligation to revoke and issue new State Administrative Decrees.

4. Obligation to pay compensation.

5. Obligation to carry out rehabilitation in a dispute

6. staffing.

a. Decisions that have obtained permanent legal force (inkracht Van Gewijsde), namely a court ruling that cannot be applied for legal remedies against the ruling. So that the types of content and the nature of other decisions such as declarations, claims are not accepted, claims are dropped, moreover the lawsuit is rejected cannot be subject to forced effort because it is not a condemnatory verdict.

2. The burden of paying forced money

Regarding the burden of accountability of public officials for the loss of third parties, Bambang Sugiono, states that there are two theories, namely:

a. The theory of Fautes Personalles, namely the theory which states that losses to third parties are charged to officials who because their actions result in losses.

b. The Fautes de Service theory, namely the theory which states that losses to third parties are borne by the relevant official agencies. Supandi, stated that theoretically an official who is carrying out his duties then he is carrying out the role of the state $^{4}$, therefore when in carrying out his role / duty it results in the loss of people / society as long as the duties are carried out according to law, then the loss is suffered by the person / community is charged payment to the state because it is classified as "official error". What is different from when an official does not obey the judge's decision (which can be likened to not obeying the law), then at that time he is not carrying out the role of the state (because ideally, carrying out the country's role is implementing legal provisions), therefore the risk from noncompliance with the law it cannot be borne by state finances but must be borne personally from the person in office, because this is a "personal mistake"

c. Which is in line with the 'error' theory developed from the Counseil d'Etat jurisprudence, which basically distinguishes between Faute de Serve and Faute Personalle, because the State Administration Agency does not want to implement the Tata Court decision State businesses that have legal powers can still be considered to have committed illegal acts personally. So that the burden of payment of forced money must be borne by him, even though in practice there can be difficulties if during the implementation phase it turns out that the official moves out of the State Administrative Court or outside the area and if the salary is not enough to pay forced money. . However, this can be achieved by coordinating between the State Administrative Courts with one another and the way payments are made in installments. 5

\footnotetext{
${ }^{1}$ R. Soegijanto Tjakranegara, 2002, Hukum Acara Peradilan Tata Usaha Negara di Indonesia, Jakarta, Sinar Grafika, p. 67.

${ }^{2}$ Bambang Sugiono, 2004, Penerapan Upaya Paksa dalam Putusan Pengadilan Tata Usaha Negara, Jakarta, 28 Agustus 2004, Makalah Workshop, p. 3

${ }^{3}$ Ibid, p. 7

${ }^{4}$ Supandi, 2004, Problematika Penerapan Eksekusi Putusan Peradilan Tata Usaha Negara terhadap Pejabat Tata Usaha Negara Daerah, Jakarta, 28 Agustus 2004, Makalah Workshop, p. 2-3.

${ }^{5}$ Paulus Effendi Lotulung, 2013, Hukum Tata Usaha Negara dan Kekuasaan, Jakarta, Salemba Humanika, p. 15
} 


\section{When the forced money is applied}

Enforcement of forced payments is made from the expiry of the period of ruling / order of the Chairperson of the Administrative Court as referred to in Article 116 paragraph (3) of the Administrative Court Law (therefore in the Decision Letter / Order of the Chair must be stated the time limit for the implementation of Court Decisions) and subsequently after the decision period The Court, the Chairperson of the Court makes a Determination addressed to the Head of the authorized KPN which contains the order that the Head of the KPN deduct the Defendant's salary every month, the amount of which is determined in the Decision until the Defendant complies with the decision until it has permanent legal force.

4. The State Administrative Court Judge has been able to implement the Forced Effort institution even though the Forced Effort Implementing Regulation does not yet exist.

5. Mechanism of payment of forced money

Implementing forced payments to run effectively requires cooperation between the Supreme Court, Minister of Home Affairs and Minister of Finance in the form of a joint Decree or other form because the payment mechanism requires cooperation between these agencies.

The mechanism for implementing forced payments is as follows: ${ }^{1}$

1. After 3 months of the Decision of the State Administrative Court that has legal force that is still not adhered to by the Defendant (State Administration Officer), the Plaintiff can submit an application to the Chairperson of the Administrative Court so that the Officials carry out the contents of the Court Decision (Article 116 paragraph 3 ) Administrative Court Law).

2. The Chairperson of the State Administrative Court issues a Determination which contains an order to the Defendant to carry out the contents of the Court's Decision accompanied by a time limit (time limit) to carry it out, for example within 7 days after the determination was issued.

3. Determination of the Chairperson of the State Administrative Court accompanied by a copy of the Court's Decision with permanent legal force sent by the bailiff to the Defendant, and the copy sent to the Defendant's superior, the routine treasurer of the Defendant's agency and the local State Treasury Office.

4. Immediately after receiving the Decision of the Chief of Court regarding the amount of forced money and the attachment of the Court's Decision with permanent legal force, the Treasurer routinely submits a Request for Payment (SPP) for the Defendant's salary which has been adjusted to the amount of forced money charged to next month's salary request.

5. The KPKN issues a Payment Order (SPM) addressed to the Plaintiff through the local State Administrative Court.

6. With these SPM the Local Administrative Court disburses forced money to the designated Bank.

7. Not later than 7 days after the money is disbursed, Jurisita must submit the payment of the forced money to the Plaintiff or his heir.

The implementation of a decision has 2 (two) efforts that can be taken, namely:

1. Direct forced effort (directe middelen), namely the plaintiff obtains the achievement of the defendant in accordance with what was determined or ordered by the judge. This effort can be divided into 2 (two) ways, namely:

a. Real execution, that is, directly the defendant is forced to fulfill what was ordered by the judge. This method is to make achievements in the form of giving up an item other than money. ${ }^{2}$

b. The penalty for fulfilling an achievement in the form of payment of a sum of money is carried out by first confiscating the plaintiff's movable and immovable property, then the item is auctioned and the proceeds are used for payment in accordance with the amount paid by the defendant (verhaal executive)

2. Indirect forced efforts (indirecte middelen), namely the achievement of achievements is achieved through physical pressure to the defendant to voluntarily fulfill the achievements, this effort is known in two ways, namely:

a. The recitation of the gijzeling (hostage), namely the judge stipulates that if the convict does not want to fulfill the prescribed prestige, the convict will be held hostage. The implementation of this hostage can be applied in the court decision. The current implementation of hostages is not permitted in accordance with the Circular of the Supreme Court of the Republic of Indonesia Number 2 of 1964 because it contradicts the Pancasila.

b. Application of Dwangsom, namely the judge establishes an additional sentence for the convicted person to pay a sum of money to the plaintiff in this case if the convicted person does not fulfill the basic sentence, the additional sentence is intended to suppress the convicted person to voluntarily fulfill the basic sentence.

2. The Executorial Strength of the Decision of the State Administrative Court

\footnotetext{
${ }^{1}$ Suparto Wijoyo, 2005, Karakteristik Hukum Acara Peradilan Tata Usaha Negara, Yogyakarta, UNAIR Press, p. 67

${ }^{2}$ Indonesia, Surat Edaran Mahkamah Agung RI Nomor 2 Tahun 1964 tentang Penghapusan Sandera (Gijzeling).
} 
The weakness of the implementation of the State Administrative Court Decision is because there is no executorial institution and forcing force in the implementation of the State Administrative Court Decision, so that the implementation of the State Administrative Court Decision depends on the awareness and initiative of the State Administration Officer. Law Number 9 of 2004 concerning Amendment to Law Number 5 of 1986 concerning State Administrative Courts, Article 116 paragraph (4) and paragraph (5), namely the imposition of sanctions for State Administrative Officers who do not implement a decision that has legal force still in the form of payment of forced money (dwangsom) and / or administrative sanctions and publications in print media. Law Number 51 of 2009 concerning the Second Amendment to Law Number 5 of 1986 concerning State Administrative Courts in which Article 116 paragraph (6) in addition to regulated efforts as stipulated in the previous law, also stipulates reporting of disobedience State Administration Officers to implement the decision of the State Administrative Court to the President as the highest government power holder and to the people's representative institutions to carry out the supervisory function. However, there are still many obstacles in implementing the efforts of the enforcer, both the implementation of dwangsom / forced money and administrative sanctions.

The procedural process of the State Administration is not known for the immediate implementation of a final court decision. Only court decisions that have permanent legal force can be implemented. Court decisions that have permanent law are: ${ }^{1}$

1. First-degree court verdict that cannot be resisted or requested for another appeal;

2. A high court ruling that has not been requested for an appeal.

3. Decision of the Supreme Court in the appeal.

The implementation of a State Administrative Decision is carried out by registered mail, which is sent by the clerk of the local State Administrative Court on the order of the head of the court who judges at the first level no later than 14 (fourteen) working days. After 60 (sixty) working days the court decision is sent and the defendant does not voluntarily carry out the contents of the decision, the disputed State Administrative decision has no legal force. The problem is that by not having the legal power of a State Administrative decision, it has fulfilled the sense of justice of the people. Many cases, for example in the case of the State Administrative Decision to dismantle a building, at the time of the Decision of the State Administrative Court which declared the invalidity of the decision of the State Administration office, it turned out that the building had been dismantled. And the State Administration Officers do not want to voluntarily run the Decision of the State Administrative Court, then an automatic execution occurs after 60 (sixty) working days The Decision of the State Administration Officer has no legal force. But with this automatic execution, it did not return the people's losses for the demolition of the building.

The real nature of coercion such as hostage taking and forced fines to State Administration Officers is unknown in the State Administrative Procedure Law, therefore the implementation of coercion against State Administration Officers to carry out State Administrative Decisions is a voluntary administration of the State Administration concerned. If this coercion is possible it must be remembered that: ${ }^{2}$

1. Property that is used for public purposes cannot be placed in confiscation of execution.

2. Obtaining the power to carry out on their own at the expense of the government (executed party) will be a matter that is contrary to the principle of legality which says that doing something or deciding something based on public law is solely carried out by an authorized State Administration or Agency or based on statutory provisions.

3. Seizing the freedom of people who are holding government positions as a means of coercion will result in great reflection on the course of government.

4. The government is always considered able and able to pay (solvabel).

\section{Regional Autonomy as an Obstacle in the Implementation of the Decree of the State Administration}

Regional Autonomy currently in Indonesia is regulated by Law Number 23 of 2014 concerning Regional Government. The implementation of regional autonomy in Indonesia has the following directions and objectives:

1. Increasing Community Welfare

a. Improved service to the community.

b. Empowerment and community participation.

2. Increasing Regional Competitiveness

a. Is a manifestation of democracy, justice and equality.

b. A form of concern for diversity and specificity in Indonesia.

c. Maintenance of harmonious relations between the Central Government and the Autonomous Region and between autonomous regions within the framework of the Unitary State of the Republic of Indonesia.

The implementation of regional autonomy in Indonesia because it saw the development that took place in

\footnotetext{
${ }^{1}$ Wicipto Setiadi, 2004, Hukum Acara Pengadilan Tata Usaha Negara, Jakarta, Raja Grafindo Persada, p. 98.

${ }^{2}$ Darwan, 2008, Strategi Menangani Perkara Tata Usaha Negara, Bandung, Citra Aditya Bhakti, p.. 87
} 
Indonesia experienced a very large gap between the center and the regions as well as the absence of equitable development outcomes. Regions as owners of development potential such as natural resources and other service potentials actually do not get a share of results in a balanced portion from the Central Government. Regional resources are absorbed but the results cannot be maximized by the people in the area. Regional autonomy is carried out as a manifestation of real democracy by local people. The previous law was a turning point for regional governance to be autonomous, before all regional arrangements were carried out by the Central Government, in other words the Regional Government did not have the authority to regulate its own area. This centralized system makes regional needs less able to be accommodated properly, where in each region of course have different characteristics and have different needs between regions with one another. Because of this condition, the real needs of the people in the regions cannot be fulfilled properly or are slowly realized. Starting from this, regional autonomy was implemented. Article 1 number 6 of Act Number 23 of 2014 concerning Regional Government states that Regional Autonomy is the right, authority and obligation of autonomous regions to regulate and manage Government Affairs and the interests of the local community in the system of the Unitary State of the Republic of Indonesia. ${ }^{1}$

The Regional Head and Deputy Regional Head are elected in one pair of candidates who are carried out democratically based on direct, general, free, confidential, honest and fair principles. This direct election has a considerable psychological impact on the hierarchical relationship between the regional head and the President, as if the Regional Head does not have the authority to be responsible to the President because the Regional Head is directly elected by the people and is directly responsible to the voting people. The specialty of the implementation of the PTUN ruling was the possibility of the intervention of the President as the Head of Government. In this case the President as Head of Government is responsible for fostering Civil Servants / government officials. The President, as the Head of Government who is responsible for fostering government apparatus, is certainly responsible so that each government apparatus can comply with all applicable laws and regulations including the Administrative Court Decision. The interference of the President is indeed necessary considering that the implementation of the court's decision is not as easy as criminal or civil, considering that the defendant is always the State Administration Agency. Article 116 paragraph (6) of Law Number 51 of 2009 concerning State Administrative Courts, which reads: "Besides being announced to the local printed mass media as referred to in paragraph (5), the head of the court must submit this matter to the President as the holder of power the highest government to order these officials to carry out court decisions, and to the people's representative institutions to carry out the supervisory function. " But with regional autonomy it has the psychological impact of the relationship between the President and the Regional Head, so that the Regional Head does not necessarily want to obey the President's orders. In addition, the President's intervention in the implementation of the Decision of the State Administrative Court can be confusing in the separation of executive and judicial authority. Even the President's authority will be at stake if the President often carries out these orders, because it is still very difficult for the community to distinguish between the role of the President as head of state or as head of Government. In addition, the State Administrative Court Law does not emphasize the necessity of the President to comply with the notice from the court. Therefore there is a possibility that the defendant will not implement the decision. If that happens, there will be no further efforts against the defendant, this is what is called floating execution. Another effort that can be taken is to file a claim for compensation payments to the District Court.

Other sanctions that can be imposed on State Administration officials who are not willing to implement the Decision of the State Administrative Court are administrative sanctions. Administrative sanctions that can be given based on Government Regulation Number 53 of 2010 concerning Discipline of Civil Servants are disciplinary penalties in the form of:

1. demotion,

2. Exemption from Position,

3. Resignation with respect,

4. Dismissal is not respectful.

The administrative sanction in the form of exemption from office is the most appropriate because at the time he did not comply with the Decision of the State Administrative Court, at that time he did not want to use the authority of his position. The order for the imposition of administrative sanctions is directed at officials authorized to punish the State Administration Officer. However, in the case if the State Administration Officer is a governor and regent because in accordance with the Regional Autonomy Law hierarchy does not have a superior as an official who has the authority to punish, in this case the judge can of course choose the imposition of forced money (dwangsom). Even though the implementation rules regarding forced money itself still do not exist so they are still hanging.

${ }^{1}$ Indonesia, Undang-Undang Nomor 23 Tahun 2014 tentang Pemerintahan Daerah, Pasal 1 angka 6 menyatakan bahwa Otonomi Daerah adalah hak, wewenang, dan kewajiban daerah otonom untuk mengatur dan mengurus sendiri Urusan Pemerintahan dan kepentingan masyarakat setempat dalam sistem Negara Kesatuan Republik Indonesia. 
State Administration Officers are required to rehabilitate the plaintiff's position, dignity and status so that a copy of the decision is sent to the State Administration Officer who is obliged to carry out the rehabilitation within 30 days after the decision has permanent legal force. In practice this is not easy, that is for the administration, for example if the position left behind has been replaced, this will be a related problem. In this condition the State Administration Officer cannot carry out rehabilitation perfectly because the change in circumstances after the verdict has permanent legal force, for a situation such as this the State Administration Officer must notify the plaintiff and the head of the court to submit a request to the PTUN chairman authorized. Within 30 days after notification the plaintiff gets money.

\section{E. Conclusion}

Dwangsom can only be applied to orders to carry out certain actions carried out by certain people and cannot be replaced / represented by others. The application of dwangsom cannot be applied to all PTUN decisions. The application of dwangsom can only be imposed on punishable PTUN decisions (condemnator decisions).

The implementation of Forced Efforts in the State Administrative Court has not been effective because there are no implementing regulations, only decisions that are in nature contain the burden or obligation to take certain actions to the Defendant alone which can be subject to Forced Efforts. The burden of forced money payments should be borne by the Agency / Officer of the State Business Unit personally because the act of not implementing the Court's decision is classified as a personal mistake rather than an official mistake. The effectiveness of forced money (dwangsom) as an administrative sanction has not been carried out optimally, because there are still many who violate the regulations and the application of sanctions is not firm by the implementing government.

Regional autonomy is carried out as a manifestation of real democracy by local people. The previous law was a turning point for regional governance to be autonomous, before all regional arrangements were carried out by the Central Government, in other words the Regional Government did not have the authority to regulate its own area. This centralized system makes regional needs less able to be accommodated properly, where in each region of course have different characteristics and have different needs between regions with one another. Because of this condition, the real needs of the people in the regions cannot be fulfilled properly or are slowly realized.

\section{References}

Books

Bambang Sugiono, 2004, Penerapan Upaya Paksa dalam Putusan Pengadilan Tata Usaha Negara, Makalah Workshop, 28 Agustus 2004, Jakarta.

C.S.T. Kansil, 1996, Hukum Acara Peradilan Tata Usaha Negara, Pradnya Paramita, Jakarta.

Darwan, 2008, Strategi Menangani Perkara Tata Usaha Negara, Citra Aditya Bhakti, Bandung.

Marbun S. F, 2003, Peradilan Hukum Administrasi dan Upaya Administrasi di Indonesia, Jogjakarta.

Martiman Prodjohamidjojo, 2002, Hukum Acara Pengadilan Tata Usaha Negara, Ghalia Indonesia, Jakarta.

Paulus Effendie Lotulung, 2000, Beberapa System Tentang Control Segi Hukum Terhadap Pemerintahan, Bhuana Ilmu Populer, Jakarta.

-------, 2013, Hukum Tata Usaha Negara dan Kekuasaan, Salemba Humanika,Jakarta.

R. Soegijanto Tjakranegara, 2002, Hukum Acara Peradilan Tata Usaha Negara di Indonesia, Sinar Grafika, Jakarta.

R. Wiryono, 2007, Hukum Acara Peradilan Tata Usaha Negara, Sinar Grafika, Jakarta.

Soemaryo, 1999, Tuntunan Praktek Beracara Di Peradilan Tata Usaha Negara, Primamedia Pustaka, Jakarta.

Supandi, 2002, Ganti Rugi Akibat Tindakan Pejabat Pemerintah Dalam RUU Administrasi Pemerintahan Dan Prospek Peradilan Tata Usaha Negara, PT. Sofemdia, Medan.

--------, 2004, Problematika Penerapan Eksekusi Putusan Peradilan Tata Usaha Negara terhadap Pejabat Tata Usaha Negara Daerah, Makalah Workshop, 28 Agustus 2004, Jakarta.

Suparto Wijoyo, 2005, Karakteristik Hukum Acara Peradilan Tata Usaha Negara, UNAIR Press, Yogyakarta.

Tahir Azhari, 1995, Negara Hukum Indonesia, Analisi Yuridis Normatif Tentang Unsur-Unsurnya Dalam Peradilan TUN, Universitas Indonesia, Jakarta.

Titik Triwulan T, 2011, Hukum Tata Usaha Negara Dan Hukum Acara Peradilan Tata Usaha Negara Indonesia, Kencana Prenada Media Grup, Jakarta.

Wicipto Setiadi, 2004, Hukum Acara Pengadilan Tata Usaha Negara, Raja Grafindo Persada, Jakarta,

Law

Indonesia, Undang-Undang Dasar Negara Keatuan Republik Indonesia Tahun 1945

--------, Undang-Undang Republik Indonesia Nomor 5 Tahun 1986 tentang Peradilan Tata Usaha Negara 
Undang-Undang Republik Indonesia Nomor 9 Tahun 2004 tentang Perubahan atas Undang-Undang Nomor 5 Tahun 1986 tentang Peradilan Tata Usaha Negara.

--------, Undang-Undang Republik Indonesia Nomor 51 Tahun 2009 tentang Perubahan Kedua atas UndangUndang Nomor 5 Tahun 1986 tentang Peradilan Tata Usaha Negara.

-------, Undang-Undang Nomor 23 Tahun 2014 tentang Pemerintahan Daerah.

-------, Surat Edaran Mahkamah Agung RI Nomor 2 Tahun 1964 tentang Penghapusan Sandera (Gijzeling) 